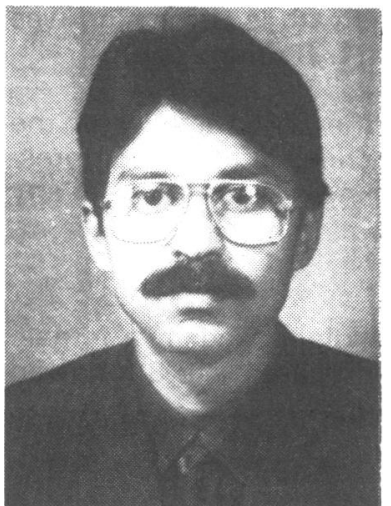

A. K. Ghosh

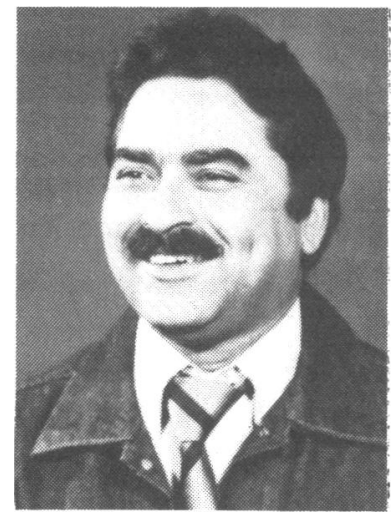

A. Ahuja

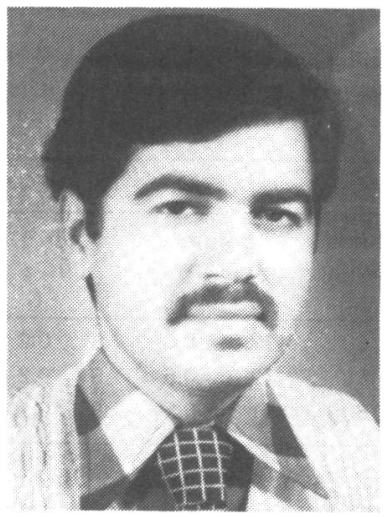

G. L. Khanna

\title{
PULMONARY CAPACITIES OF DIFFERENT GROUPS OF SPORTSMEN IN INDIA
}

\author{
A. K. GHOSH, MSc, PhD, A. AHUJA, MB, BS* and G. L. KHANNA, MSc
}

National Institute of Sports, PATIALA, India

\section{ABSTRACT}

Pulmonary functional capacities, vital capacity (VC) maximum voluntary ventilation (MVV), forced expiratory volume in 1 second and FEV 1.0 (per cent VC) of 168 sportsmen belonging to different sports activities and of 10 sedentary individuals have been studied. It was observed that all these pulmonary functional capacities of different groups of sportsmen were higher than those of the sedentary group. The mean VC of the basketball, boxing, cricket, football, hockey and the table tennis groups, the mean MVV of all the groups except the athletic, badminton and football groups, and the mean FEV 1.0 of football, hockey, swimming and volleyball groups were significantly higher than those of the sedentary group. The mean values of all the three pulmonary functional capacities of only the hockey group were found to be significantly higher than those of the sedentary individuals. The available reported pulmonary capacity values, except FEV 1.0 of a few groups of sportsmen studied abroad, were higher than those of their counterparts studied here. These might be due to the ethnic variation as well as the variation in age, body size and level of physical fitness which influence the different pulmonary capacities.

\section{INTRODUCTION}

The lung function tests, like other physiological tests must be of the utmost importance for measuring the fitness of an individual from a physiological point of view (Åstrand and Rodahl, 1970). The pulmonary functional capacities of normal sedentary individuals have been studied extensively in India (Singh, 1959; Rao et al, 1961; Singh, 1967; Jain and Ramiah, 1969; Gupta et al, 1979). In the context of an athletic population, such studies are rather scanty and have also been carried out by the researchers on a small sample (Malhotra et al, 1972; De et al, 1979, 1982).

Hence, the present study was undertaken with a view to determine the pulmonary functional capacities of the different groups of sportsmen in India and to compare them with those of sedentary persons as well as the sportsmen studied abroad by others.

\section{MATERIALS AND METHODS}

The subjects of the present study consisted of 168 sportsmen of repute who came to the National Institute of Sports, Patiala, for 10 months regular course in coaching. During their course, a training programme was administered for about 5 days a week and $3 \mathrm{hrs}$ a day in their

*Address for correspondence:

Dr. A. Ahuja

Dept. of Sports Medicine

Faculty of Sports Sciences

Netaji Subhas National Institute of Sports

Patiala

India 147001 respective discipline. The study was conducted after the completion of 9 months training. Obviously, it was assumed that all the sportsmen were physically well-trained. The sportsmen were of at least University level. A few of them have represented national and international level competitions.

Before administering the lung function tests, the height and weight of the subjects were measured. The lung volumes which have been recorded and measured on a wet spirometer included vital capacity (VC), maximum voluntary ventilation (MVV) and forced expiratory volumes at 1.0 sec (FEV 1.0). The well established methodology of Comroe et al (1963) was followed. All the subjects performed the tests in a sitting posture. The lung volumes have been expressed in BTPS.

\section{RESULTS}

The mean and standard deviation of age, height and weight of different groups of sportsmen and of sedentary persons are presented in Table I. Table II exhibits the mean and standard deviations of VC, MVV and FEV 1.0 of the different athletic groups and of normal sedentary group. The mean values of anthropometric characteristics and of pulmonary functional capacities of different groups of sportsmen have been compared by means of Student's ' $t$ ' distribution test, and the level of significance have been shown below the tables.

\section{DISCUSSION}

The mean VC of the normal sedentary person in the present investigation was $3.61 \mathrm{~L}$ and of the sedentary persons reported by previous researchers were between 3.5 to $4.0 \mathrm{~L}$ 
TABLE I

Means and standard deviation values of age, height and weight of the sportsmen in different events (Numbers in parentheses denote the ranges)

\begin{tabular}{|c|c|c|c|c|}
\hline Game & "n" & Age (yrs) & Height (cm) & Weight (kg) \\
\hline Athletics & 15 & $\begin{array}{c}26.7 \pm 2.6 \\
(24.6-32.0)\end{array}$ & $\begin{array}{cc}169.5 \pm & \pm .0 \\
(157.5-184.0)\end{array}$ & $\begin{array}{c}62.9 \pm 4.5 \\
(53.5-71.0)\end{array}$ \\
\hline Badminton & 9 & $\begin{array}{c}28.8 \pm 3.5 \\
(23.0-33.0)\end{array}$ & $\begin{array}{c}171.6 \pm \quad 6.6 \\
(161.0 \pm 180.0)\end{array}$ & $\begin{array}{c}69.3 \pm 11.3 \\
(56.0-82.5)\end{array}$ \\
\hline Basketball & 10 & $\begin{array}{c}28.3 \pm 4.0 \\
(23.0-35.0)\end{array}$ & $\begin{array}{c}180.1 \pm 9.7^{* *} \\
(165.0-199.0)\end{array}$ & $\begin{array}{c}68.1 \pm 10.0 \\
(62.0-95.0)\end{array}$ \\
\hline Boxing & 9 & $\begin{array}{c}26.0 \pm 2.1 \\
(23.0-30.0)\end{array}$ & $\begin{array}{c}174.4 \pm 9.0 \\
(164.0-188.0)\end{array}$ & $\begin{array}{c}68.2 \pm 10.0 \\
(49.0-80.0)\end{array}$ \\
\hline Cricket & 9 & $\begin{array}{c}28.6 \pm 2.4 \\
(24.0-31.0)\end{array}$ & $\begin{array}{cc}174.4 \pm & 6.5 \\
(168.0-190.5)\end{array}$ & $\begin{array}{c}64.8 \pm 9.2 \\
(51.0-82.3)\end{array}$ \\
\hline Football & 25 & $\begin{array}{c}29.6 \pm 2.4 \\
(23.0-37.0)\end{array}$ & $\begin{array}{c}169.2 \pm \quad 4.8 \\
(157.5-178.0)\end{array}$ & $\begin{array}{c}62.5 \pm 6.4 \\
(54.0-78.0)\end{array}$ \\
\hline Gymnastics & 15 & $\begin{array}{c}25.7 \pm 2.2 \\
(22.0-31.0)\end{array}$ & $\begin{array}{c}165.5 \pm 4.6 \\
(160.0-177.0)\end{array}$ & $\begin{array}{c}60.9 \pm 5.9 \\
(52.0-74.0)\end{array}$ \\
\hline Hockey & 14 & $\begin{array}{c}28.1 \pm 3.7 \\
(25.0-34.0)\end{array}$ & $\begin{array}{c}171.8 \pm 6.6 \\
(160.0-183.0)\end{array}$ & $\begin{array}{l}(65.8 \pm 5.6) \\
(58.0-74.5)\end{array}$ \\
\hline Swimming & 11 & $\begin{array}{c}27.4 \pm 2.9 \\
(24.0-32.0)\end{array}$ & $\begin{array}{c}170.2 \pm \quad 8.0 \\
(157.0-182.0)\end{array}$ & $\begin{array}{c}65.8 \pm 6.3 \\
(57.7-77.0)\end{array}$ \\
\hline Table Tennis & 6 & $\begin{array}{c}27.4 \pm 4.4 \\
(20.0-32.0)\end{array}$ & $\begin{array}{c}178.0 \pm \quad 7.8^{*} \\
(169.0-185.0)\end{array}$ & $\begin{array}{c}64.4 \pm 7.1 \\
(56.0-75.0)\end{array}$ \\
\hline Volleyball & 14 & $\begin{array}{c}28.0 \pm 2.7 \\
(24.0-31.0)\end{array}$ & $\begin{array}{cc}173.8 \pm & 6.5 \\
(162.5-183.0)\end{array}$ & $\begin{array}{c}66.7 \pm 8.7 \\
(52.0-78.0)\end{array}$ \\
\hline Weightlifting & 12 & $\begin{array}{c}28.4 \pm 3.9 \\
(23.0-34.0)\end{array}$ & $\begin{array}{c}167.3 \pm 4.4 \\
(161.0-176.0)\end{array}$ & $\begin{array}{c}70.4 \pm 9.8^{*} \\
(57.0-90.0)\end{array}$ \\
\hline Wrestling & 21 & $\begin{array}{c}26.9 \pm 3.8 \\
(23.0-34.0)\end{array}$ & $\begin{array}{c}169.4 \pm \quad 6.1 \\
(160.0-183.0)\end{array}$ & $\begin{array}{c}65.9 \pm 8.0 \\
(54.0-81.6)\end{array}$ \\
\hline $\begin{array}{l}\text { Sedentary } \\
\text { control group }\end{array}$ & 10 & $\begin{array}{c}26.8 \pm 4.2 \\
(22.0-34.0)\end{array}$ & $\begin{array}{c}169.0 \pm 5.3 \\
(162.5-178.0)\end{array}$ & $\begin{array}{c}59.6 \pm 7.3 \\
(52.0-75.0)\end{array}$ \\
\hline
\end{tabular}

${ }^{*} p<0.05$ (compared to the sedentary persons)

** $p<0.01$ (compared to the sedentary persons)

(Singh, 1959; Kashliwal et al, 1964; Jain and Ramiah, 1969; Ghosh, 1981). The mean VC of all the different groups of sportsmen studied here, were higher not only than that of the sedentary persons studied here, but also of those of the above reported cases. This supports the findings of Stuart and Collings (1959) who observed that the VC of the sportsmen were higher than the normal sedentary persons.

The mean MVV and FEV 1.0 of all the groups of sportsmen were higher than those of the sedentary control group studied here. In the athletics and badminton groups, the differences of mean MVV were not statistically significant. On the other hand, statistically significant differences between the mean FEV 1.0 were observed in the swimming, volleyball, hockey and football groups. In previous studies on normal Indian sedentary population (Singh, 1959; Rao et al, 1961; Kashliwal et al, 1964; Jain and Ramiah, 1969; Ghosh, 1981), the mean MVV and FEV 1.0 were observed to be not higher than $139.09 \mathrm{~L}$ per min and 81 per cent, respectively. The present findings revealed that the basketball, swimming, volleyball, hockey and table tennis groups exhibited higher mean values of MVV than the reported values on sedentary persons in India. On the other hand, the mean FEV 1.0 of almost all the groups of sportsmen exhibited higher values than those reported by the other authors on sedentary persons in India.

Hence, it can be stated here that the physically trained individuals, may have higher ventilatory capacity as well as FEV 1.0. This might have been brought about by the fact that physical training not only improves the strength of skeletal limb and cardiac muscle, but also improves the accessory muscles for inspiration and expiration (Stuart
TABLE II

Mean and standard deviation values of VC, MVV and FEV 1.0 of different groups of sportsmen and of sedentary individuals (Numbers in parentheses denote the ranges)

\begin{tabular}{|c|c|c|c|}
\hline Game & VC (L.BTPS) & MVVL (L/min, BTPS) & .FEV $1.0(\%)$ \\
\hline Athletics & $\begin{array}{c}4.06 \pm 0.78 \\
(3.00-5.73)\end{array}$ & $\begin{array}{l}123.0 \pm 28.4 \\
(91.2-177.2)\end{array}$ & $\begin{array}{c}90.9 \pm 5.0 \\
(78.4-98.0)\end{array}$ \\
\hline Badminton & $\begin{array}{c}4.00 \pm 0.63 \\
(3.36-4.97)\end{array}$ & $\begin{array}{l}118.7 \pm 21.5 \\
(91.6-148.0)\end{array}$ & $\begin{array}{c}84.7 \pm 7.8 \\
(76.6-97.1)\end{array}$ \\
\hline Basketball & $\begin{array}{l}4.73 \pm 0.74^{* *} \\
(4.05-6.61)\end{array}$ & $\begin{array}{c}155.0 \pm 26.4^{* *} \\
(120.6-192.0)\end{array}$ & $\begin{array}{c}90.0 \pm 6.5 \\
(80.0 \pm 6.5)\end{array}$ \\
\hline Boxing & $\begin{array}{c}4.52 \pm 0.80^{*} \\
(3.58-5.71)\end{array}$ & $\begin{array}{l}146.0 \pm 38.6^{*} \\
(95.0-222.7)\end{array}$ & $\begin{array}{c}88.1 \pm 6.7 \\
(78.4-96.4)\end{array}$ \\
\hline Cricket & $\begin{array}{c}4.25 \pm 0.74^{*} \\
(3.38-5.11)\end{array}$ & $\begin{array}{r}136.5 \pm 17.9^{*} \\
(118.0-158.7)\end{array}$ & $\begin{array}{c}88.0 \pm 4.7 \\
(80.4-96.4)\end{array}$ \\
\hline Football & $\begin{array}{c}4.10 \pm 0.50^{*} \\
(3.23-5.11)\end{array}$ & $\begin{array}{l}126.0 \pm 29.2 \\
(80.0-219.2)\end{array}$ & $\begin{array}{l}90.0 \pm 5.1^{* *} \\
(81.4-97.0)\end{array}$ \\
\hline Gymnastics & $\begin{array}{c}4.04 \pm 0.67 \\
(3.23-5.25)\end{array}$ & $\begin{array}{c}137.7 \pm 24.8 * * \\
(101.2-185.2)\end{array}$ & $\begin{array}{c}85.4 \pm 5.8 \\
(77.0-92.2)\end{array}$ \\
\hline Hockey & $\begin{array}{l}4.48 \pm 0.80^{* *} \\
(3.22-5.77)\end{array}$ & $\begin{array}{c}145.8 \pm 24.9 \\
(109.6-186.3)\end{array}$ & $\begin{array}{c}90.5 \pm 4.9^{*} \\
(80.6-97.5)\end{array}$ \\
\hline Swimming & $\begin{array}{c}4.01 \pm 0.44 \\
(3.43-4.88)\end{array}$ & $\begin{array}{c}144.5 \pm 23.8^{* *} \\
(106.6-180.6)\end{array}$ & $\begin{array}{c}91.2 \pm 4.0^{*} \\
(84.4-97.5)\end{array}$ \\
\hline Table Tennis & $\begin{array}{c}4.42 \pm 0.79^{*} \\
(3.42-5.78)\end{array}$ & $\begin{array}{c}140.7 \pm 20.7^{*} \\
(109.1-165.8)\end{array}$ & $\begin{array}{c}85.5 \pm 8.7 \\
(74.0-98.7)\end{array}$ \\
\hline Volleyball & $\begin{array}{c}4.06 \pm 0.72 \\
(3.00-5.16)\end{array}$ & $\begin{array}{c}150.2 \pm 26.4^{* *} \\
(109.0-193.0)\end{array}$ & $\begin{array}{c}92.1 \pm 5.0^{* *} \\
(82.0-98.7)\end{array}$ \\
\hline Weightlifting & $\begin{array}{c}4.01 \pm 0.61 \\
(2.83-4.87\end{array}$ & $\begin{array}{c}138.2 \pm 22.2^{*} \\
(107.4-176.7)\end{array}$ & $\begin{array}{c}87.7 \pm 6.1 \\
(78.3-98.0)\end{array}$ \\
\hline Wrestling & $\begin{array}{c}4.02 \pm 0.73 \\
(2.86-5.55)\end{array}$ & $\begin{array}{l}138.8 \pm 23.2^{* *} \\
(100.0-181.4)\end{array}$ & $\begin{array}{c}90.8 \pm 6.4 \\
(78.0-97.1)\end{array}$ \\
\hline $\begin{array}{l}\text { Sedentary } \\
\text { control group }\end{array}$ & $\begin{array}{c}3.61 \pm 0.67 \\
(2.98-4.05)\end{array}$ & $\begin{array}{r}110.5 \pm 23.2 \\
(62.7 \pm 142.0\end{array}$ & $\begin{array}{c}84.0 \pm 6.8 \\
(71.6-93.7)\end{array}$ \\
\hline
\end{tabular}

${ }^{*} p<0.05$ (compared to the sedentary persons)

**p $<0.01$ (compared to the sedentary persons)

and Collings, 1959; Cotes, 1965; Maksud et al, 1971) was reported to be $5.134 \mathrm{~L}$. In another study, on United States Olympic freestyle wrestlers, Rasch and Brant (1957) observed a mean VC of $5.232 \mathrm{~L}$, a mean FEV 1.0 of 80.1 per cent and a mean MVV of $163.56 \mathrm{~L}$ per min which were although higher than the predicted normal values, yet not found to be statistically significant. In the present study, the mean VC and MVV were much lower than the reported values of abroad. The reason might be due to several factors; age, height, weight, race and level of physical fitness. The mean FEV 1.0 of the wrestlers in the present investigation were higher than that of the Olympians stated above. This denotes that the efficiency of the respiratory muscles may account for a high value of FEV 1.0 of (Stuart and Collings, 1959). McKay et al (1983) reported mean VC and FEV 1.0 of the international swimmers to be $6.10 \mathrm{~L}$ and 93.4 per cent which were also higher than that of the swimmers of the present study. The international level swimmers had a higher mean body size and lower mean age than the swimmers studied here.

\section{CONCLUSIONS}

The present study concludes the following:-

(i) The vital capacity, maximum voluntary ventilation and FEV 1.0 were higher in physically trained sportsmen than in the normal sedentary control individuals. In some groups, the values differ significantly, while in others, they were not found to be statistically significant. This might be due to the fact that, as a result of physical training, the respiratory muscles also become more efficient like other skeletal muscles. 
(ii) The available reported values of a few groups of sportsmen studied abroad, were higher than the values of their counterparts studied here. These may be not only due to ethnic variations (Cotes and Malhotra, 1965) but also due to variation in age, body size and level of physical fitness.

\section{ACKNOWLEDGEMENT}

Thanks are due to the sportsmen who participated in the present investigation wholeheartedly.

\section{References}

Åstrand, P. O. and Rodahl, K., 1970. Textbook of Work Physiology. McGrawHill Kogakusa Ltd.

Comroe, J. H., Forster, R. E., Dubois, A. B., Briscoe, W. A. and Carlson, E., 1963. The Lung. Yearbook Medical Publishers Inc., Chicago.

Cotes, J. E., 1965. Lung Functions, Assessment and Application in Medicine. Blackwell Scientific Publications, Oxford.

Cotes, J. E. and Malhotra, M. S., 1965 "Differences in lung functions between Indians and Europeans". J.Physiol. 177: 17.

De, A. K., Debnath, P. K. and Nagchoudhuri, J., 1979 "A comparison of physical efficiency between volleyball and kabaddi players". SNIPES J. 2 (2): 46-50.

De, A. K., Dasgupta, P. K., Panda,B. K. and Bhattacharya, A. K., 1982 “Physical efficiency tests on Indian male kabaddi Inter-University players". Brit.J. Sports Med. 16 (1): 33-36.
Ghosh, A. K., 1981 "Selection of clinically suitable tests/methods for ergonomic/physiological evaluation of lower extremity handicapped persons". PhD Thesis, Calcutta University.

Gupta, P., Gupta, L. and Ajmer, R. L., 1979 "Lung functions in Rajasthan subjects". Ind.J.Physiol.Pharmacol. 23 (1): 9-14.

Jain, S. K. and Ramiah, T. J., 1969 "Normal standards of pulmonary function tests for healthy Indians 15-40 yrs old, comparison of different prediction equations". Ind.J.Med.Res. 57: 1433-1466.

Kashliwal, R. M., Baldwa, V. S. and Sharma, P. R., 1964 "Ventilatory tests and lung volume studies in health". J.Ind.Med.Assoc. 43: 49-54.

Maksud, M., Hamilton, L., Couths, K. and Wiley, R., 1971 "Pulmonary function movements of Olypic speed skaters from the US". Med.Sci.in Sports 3 : 66-71.

Malhotra, M. S., Ramaswamy, S. S., Joseph, N. T. and Sengupta, J., 1972 "Functional capacities and body compositions of Indian athletes". Ind.J. Physiol.Pharmacol. 6: 55-62.

McKay, E. E., Braund, R. W., Chalmer, R. J. and Williams, G. S., 1983 "Physical working capacities and lung functions in competitive swimmers". Brit.J. Sports Med. 17 (1): 27-33.

Rao, M. N., Sengupta, A., Saha, P. N. and Sita Devi, A., 1961 "Physiological norms in Indians". Indian Council of Medical Research Spl., report series no. 38.

Rasch, P. J. and Brant, J. W. A., 1957 "Measurement of pulmonary functions in United States Olympic freestyle wrestlers". Res.Quart. 28 (3): 279-287.

Singh, H. D., 1959 "Ventilatory function tests, normal standards in male adults". J.Ind.Med.Prof. 5: 2483-2486.

Singh, H. D., 1967 "Peak flow rate in Indians". Ind.J.Physiol.Pharmacol. 11: 129-130.

Stuart, D. G. and Collings, W. B., 1959 "Comparison of vital capacity and maximum breathing capacity of athletes and non-athletes". J.Appl.Physiol. 14 (4): 507-509. 